\title{
Effect of organic fertilization on growth and yield of pepper plants (Capsicum annuum L.)
}

\section{Malgorzata Berova ${ }^{1}$, Georgios Karanatsidis ${ }^{1}$, Krasimira Sapundzhieva ${ }^{1}$,Veselina Nikolova ${ }^{2}$}

\author{
${ }^{1}$ Agricultural University - Plovdiv \\ 12 Mendeleev Str., 4000 Plovdiv, Bulgaria \\ ${ }^{2}$ Institute of Vegetable Crops - Maritsa \\ 32 Brezovsko shose Str., 4003 Plovdiv, Bulgaria \\ e-mail: maberova@abv.bg
}

\begin{abstract}
The aim of this study was to investigate the effect of organic fertilization on growth, several physiological parameters and yield of pepper plants ('Buketen 50'). The field experiment was carried out at the experimental field of the Agroecological Centre of the Agricultural University of Plovdiv (Bulgaria), which is certified as an ecological farm. For the purpose of the research, the bio-fertilizer Lumbrical, produced by the Californian earthworm (Lumbricus rubellus), was used. Just before planting, two levels of the bio-fertilizer were applied 50 and $100 \mathrm{ml}$ per plant. Thirty days after planting, a part of the plants were additionally fed with a solution of Lumbrical ( $200 \mathrm{ml}$ per plant). During plant vegetation some biometrical indices characterizing plant growth were measured. The content of the plastid pigments and the leaf gas exchange were taken into account. The fertility of the pollen of the flowers was determined. The total amount of pigments in the dried and ground red pepper was analyzed.
\end{abstract}

Key words: Lumbricus rubellus, photosynthesis, pollen fertility, productivity

\section{INTRODUCTION}

Biological agriculture is an element of the system for sustainable agriculture and an alternative to traditional approaches in agriculture. It only seemingly turns back to the old agricultural systems. In its essence, this type of agriculture is based on new ecological methods and approaches, the implementation of which requires profound knowledge on behalf of the producers, substantiated with specific scientific information. This is the reason behind the comprehensive research in this field being carried out in a number of countries (Barakrt and Gabr 1998, Aliyu and Kuchinda 2002, Kostadinova et al. 2003, Stephen and Nybe 2003, Tringovska 2004, Heeb et al. 2005).

One of the agrotechnical events permitted in biological production is the use of products obtained as a result of composting of organic waste with the help of various types of earthworms (Clive et al. 2006, Gutiérrez-Miceli et al. 2007, Singh et al. 2008). Two types of worms have obtained practical application: the red Californian earthworm (Lumbricus rubellus) and the red wiggler worm (Eisenia foetida). Feeding on fermented manure, they decompose it and use it as food. Around $60 \%$ of the absorbed food is released as excrement (called 'biohumus'). The bioproduct obtained as a result of the vital activity of these worms improves soil fertility (Karbauskiene 2000) and has a very strong stimulating impact on the growth and development of plants (Atiyeh et al. 2000, Makulec 2002, Arancon et al. 2004).

\section{MATERIAL AND METHODS}

The field experiment was carried out at the Agroecological Centre of the Agricultural University in Plovdiv, Bulgaria, a holder of an ecological farm certificate. The experiment 
was carried out on the 'Buketen 50' pepper cultivar, which is intended for the production of red pepper for grinding. The seedlings were produced in a polythene greenhouse, upon cold seedbeds with tunnel covers above them. Thick seedlings were produced under the sowing norm of $12-15 \mathrm{~g} \mathrm{~m}^{-2}$. The seedlings were planted in a permanent place at the beginning of June, after a durable increase in the soil temperature to over $16^{\circ} \mathrm{C}$, on a profiled surface in the form of long furrows, with the planting scheme $60 \times 15 \mathrm{~cm}$.

For the purpose of the experiment a biofertilizer produced by the Californian earthworm Lumbricus rubellus (Lumbrical) was used. Lumbrical was placed at the bottom of previously shaped $6-8 \mathrm{~cm}$ deep furrows upon planting the seedlings on a permanent place. During vegetation, a part of the plants were treated with Lumbrical extract (30 days after the first nutrition). The extract was a water solution of Lumbrical in volume ratio 1:10. The solution was left to mature for at least 24 hours and was periodically stirred. The clear part of the sediment was decanted. The plants were treated with the extract at a ratio of $200 \mathrm{ml}$ per plant.

The experiment was carried out under the following scheme: 1. Control sample - soil without a biofertilizer; 2. Soil enriched with Lumbrical, $50 \mathrm{ml}$ per plant before planting; 3. Soil enriched with Lumbrical, $50 \mathrm{ml}$ per plant before planting and with Lumbrical extract, $200 \mathrm{ml}$ per plant after planting; 4. Soil enriched with Lumbrical, $100 \mathrm{ml}$ per plant before planting.

Picking was carried out at the beginning of October, on two occasions (when over $80 \%$ of the fruits had reached full botanical maturity and one week later). The unimpaired fruits were left to season.

Prior to the experiment, chemical and microbiological analyses were performed both on the soil and on the biofertilizer. The humus was determined using the Tiurin method. The determination of $\mathrm{pH}$ was performed potentiometrically. The total nitrogen was determined titrometrically, after burning in sulphuric acid and subsequent distillation on a Parnas-Wagner apparatus. The total content of the phosphorus was determined colorimetrically using the method of Egner - Riehm. The total quantity of potassium was determined in a hydrochloric acid extract $(2 \mathrm{~N} \mathrm{HCl})$ using the modified method of Milcheva, and the measurement was effected on a flame photometer (Tomov et al. 1999).
The number of bacteria, sporogenous bacteria, actinomycetes, microscopic fungi and cellulose decomposing bacteria were determined by the dilution agar plate method (Koleshko 1981).

60 days after the application of the Lumbrical fertilizer (30 days after the additional nutrition), several biometrical indices of the plants were measured. The content of plastid pigments according to Lichtenthaler and Wellburn (1983) and the parameters of the leaf gas exchange (with the help of the portable photosynthetic system LCA-4, ADC, England) were reported. At the same time, pollen fertility was determined on flowers from the middle levels of the plants. The pollen was coloured by a mixture of carmine and glycerin (1:1). In each flower from different fields of vision over 100 pollen grains were observed. In the phase of full maturity the fruits were dried in a drying room at $50^{\circ} \mathrm{C}$. The grinded red pepper was prepared from the fruits' pericarp. The total pigment content was determined under the ASTA -19 method, modified by Manuelyan(1979), immediately after pepper grinding.

Each of the tested variants had four replications, and each one of them included 24 plants. The experiments were carried out in the period 2007-2008. During the two years of the experiment, a similar reaction of the plants towards treatment with Lumbrical biofertilizer was observed. Due to that reason average data from two reporting years were presented in the publication. Statistical analyses were carried out by One-Way ANOVA using the Tukey test to estimate the significant difference.

\section{RESULTS AND DISCUSSION}

The soil used for the experiment had low nitrogen content, medium phosphorus content and a high quantity of potassium (Tomov et al. 1999) - Tab. 1 . The microbiological analysis (Tab. 2) showed that the quantity of bacteria mineralizing the organic nitrogen compounds and of the actinomycetes was higher in the biofertilizer compared to the soil. Irrespective of the

Table 1. Chemical characteristics of the soil

\begin{tabular}{ccccccc}
\hline $\begin{array}{c}\text { Soil layer } \\
(\mathrm{cm})\end{array}$ & $\mathrm{pH}$ & $\begin{array}{c}\text { Organic } \\
\text { matter } \\
(\%)\end{array}$ & $\begin{array}{c}\mathrm{NH}_{4}-\mathrm{N} \\
\left(\mathrm{mg} \mathrm{kg}^{-1}\right)\end{array}$ & $\begin{array}{c}\mathrm{NO}_{3}-\mathrm{N} \\
\left(\mathrm{mg} \mathrm{kg}^{-1}\right)\end{array}$ & $\begin{array}{c}\mathrm{P}_{2} \mathrm{O}_{5} \\
\left(\mathrm{mg} \mathrm{kg}^{-1}\right)\end{array}$ & $\begin{array}{c}\mathrm{K}_{2} \mathrm{O} \\
\left(\mathrm{mg} \mathrm{kg}^{-1}\right)\end{array}$ \\
\hline 20 & 7.68 & 2.9 & 6.40 & 17.95 & 105.5 & 495 \\
\hline
\end{tabular}

Table 2. Microbiological analysis of the soil and Lumbrical biofertilizer

\begin{tabular}{lcccccc}
\hline & $\begin{array}{c}\text { Bacteria mineral. } \\
\text { org. N compounds }\end{array}$ & $\begin{array}{c}\text { Sporogenous } \\
\text { bacteria }\end{array}$ & $\begin{array}{c}\text { Bacteria transf. } \\
\text { mineral. N compounds }\end{array}$ & $\begin{array}{c}\text { Actin- } \\
\text { omycetes }\end{array}$ & $\begin{array}{c}\text { Microscopic } \\
\text { fungi }\end{array}$ & $\begin{array}{c}\text { Cellulose-decomposing } \\
\text { bacteria }\end{array}$ \\
\hline Soil & $1.6 \times 10^{6}$ & $4.5 \times 10^{4}$ & $7.1 \times 10^{5}$ & $1.3 \times 10^{5}$ & $2.6 \times 10^{4}$ & $0.8 \times 10^{4}$ \\
Fertilizer & $3.7 \times 10^{6}$ & $7.7 \times 10^{4}$ & $4.9 \times 10^{5}$ & $1.9 \times 10^{5}$ & $2.5 \times 10^{4}$ & $0.6 \times 10^{4}$ \\
\hline
\end{tabular}


Table 3. Chemical characteristics of Lumbrical biofertilizer

\begin{tabular}{ccccccccc}
\hline $\begin{array}{c}\text { Dry mass } \\
(\%)\end{array}$ & $\mathrm{pH}$ & $\begin{array}{c}\text { Organic matter } \\
(\%)\end{array}$ & $\begin{array}{c}\mathrm{N} \\
(\%)\end{array}$ & $\begin{array}{c}\mathrm{NH}_{4}-\mathrm{N} \\
\left(\mathrm{mg} \mathrm{kg}^{-1}\right)\end{array}$ & $\begin{array}{c}\mathrm{NO}_{3}-\mathrm{N} \\
\left(\mathrm{mg} \mathrm{kg}^{-1}\right)\end{array}$ & $\begin{array}{c}\mathrm{P} \\
(\%)\end{array}$ & $\begin{array}{c}\mathrm{P}_{2} \mathrm{O}_{5} \\
\left(\mathrm{mg} \mathrm{kg}^{-1}\right)\end{array}$ & $\begin{array}{c}\mathrm{K} \\
(\%)\end{array}$ \\
\hline 48.8 & 7.3 & 35.4 & 1.66 & 13.6 & 144.4 & 2.15 & 283 & $\begin{array}{c}\mathrm{K}_{2} \mathrm{O} \\
\left(\mathrm{mg} \mathrm{kg}^{-1}\right)\end{array}$ \\
\hline
\end{tabular}

fact that the number of bacteria immobilizing nitrogen was reduced in the biofertilizer, the balance between the mineralization and immobilization processes was preserved and the bacteria decomposing the organic nitrogen compounds were predominant. This led to an accumulation of accessible mineral nitrogen compounds in the biofertilizer (Tab. 3).

Lumbrical biofertilizer accelerated the vegetative growth of the plants (Tab. 4). The plants' height and the crown diameter were bigger in the treated samples. The leaf number, size and mass of plants treated with a biofertilizer considerably increased compared to those of the control sample. This came as a result of the improved nutrition of the treated plants, which accelerated the growth and the accumulation of biomass of the photosynthesizing organ. The biofertilizer also influenced the generative conduct of the plants. The number and mass of the fruits formed at this stage were considerably higher in the treated plants.

Table 4. Effect of Lubrical biofertilizer on some growth parameters of pepper plants

\begin{tabular}{lcrrr}
\hline Treatments & $1^{*}$ & 2 & 3 & 4 \\
\hline Plant height $(\mathrm{cm})$ & $48.3 \mathrm{a}^{* *}$ & $52.3 \mathrm{~b}$ & $54.0 \mathrm{~b}$ & $51.6 \mathrm{~b}$ \\
Crown diameter $(\mathrm{cm})$ & $27.8 \mathrm{a}$ & $32.2 \mathrm{~b}$ & $39.5 \mathrm{c}$ & $33.5 \mathrm{~b}$ \\
Leaf number & $45.6 \mathrm{a}$ & $78.3 \mathrm{~b}$ & $97.1 \mathrm{~d}$ & $91.0 \mathrm{c}$ \\
Leaf area $\left(\mathrm{cm}^{2}\right)$ & $358.6 \mathrm{a}$ & $488.4 \mathrm{~b}$ & $536.1 \mathrm{~d}$ & $519.0 \mathrm{c}$ \\
Leaf weight $(\mathrm{g})$ & $35.0 \mathrm{a}$ & $80.9 \mathrm{~b}$ & $94.0 \mathrm{c}$ & $109.9 \mathrm{~d}$ \\
Ovarium number & $6.5 \mathrm{a}$ & $6.5 \mathrm{a}$ & $9.0 \mathrm{~b}$ & $8.1 \mathrm{ab}$ \\
Ovarium weight $(\mathrm{g})$ & $1.0 \mathrm{a}$ & $2.3 \mathrm{ab}$ & $3.0 \mathrm{~b}$ & $2.8 \mathrm{~b}$ \\
Fruit number & $14 \mathrm{a}$ & $16 \mathrm{a}$ & $16.5 \mathrm{a}$ & $21.3 \mathrm{~b}$ \\
Fruit weight $(\mathrm{g})$ & $93.7 \mathrm{a}$ & $279.3 \mathrm{~b}$ & $326.5 \mathrm{~d}$ & $310.8 \mathrm{c}$ \\
\hline
\end{tabular}

*1. Control - soil without a biofertilizer; 2. Soil enriched with Lumbrical, $50 \mathrm{ml}$ per plant before planting; 3. Soil enriched with Lumbrical, $50 \mathrm{ml}$ per plant before planting and Lumbrical extract, $200 \mathrm{ml}$ per plant after planting; 4. Soil enriched with Lumbrical, 100 $\mathrm{ml}$ per plant before planting

**Values in columns followed by the same letter do not differ significantly at $\mathrm{p}=0.05$
The positive influence of the biofertilizer upon plant growth was also determined by other authors. In the production of tomato seedlings, a more powerful root system was observed, as well as stronger stems and an increased leaf number and mass. The accelerated growth rate of the vegetative organs was also accompanied by an increased development of the generative organs (Atiyeh et al. 2000, Hashemimajd et al. 2004). At the same time, Gutiérrez-Miceli et al. (2007) observed that in greenhouse production of tomatoes, biofertilizers considerably increased plant growth but didnot significantly influence the number of leaves.

The results displayed in Table 5 show that the content of photosynthetic pigments increased in plants treated with the biofertilizer. The total chlorophyll content had its highest rates in the leaves of plants additionally treated with the Lumbrical solution. Deviation from the standard in the proportion between the pigments was not observed, which shows that all pigments were equally influenced by the treatment with Lumbrical. Biofertilizer increased the functional activity of the photosynthetic apparatus of pepper plants (Tab. 6). The photosynthesis activity increased approximately by $32 \%$ in plants treated with biofertilizer. The changes in the transpiration intensity were comparable with those in the stomatal conductance. The data referring to the increased photosynthesis speed were unidirectional with those related to the content of photosynthetic pigments. This shows that along with the stomatal conductance, the increased pigment content is one of the reasons for the increased photosynthetic speed of the plants treated with biofertilizer.

The data (Tab. 7) show that pollen fertility was highest in plants additionally treated with Lumbrical biofertilizer $(72.9 \%)$. In this variant, the variation coefficient was the lowest (VC 10.9\%). The plants treated with $100 \mathrm{ml}$ biofertilizer were the most sensitive and the variation coefficient was expressed the most (VC 22.8\%). The highest level of pollen fertility (from 80 to $100 \%$ ) was

Table 5. Photosynthetic pigment content $\left(\mathrm{mg} \mathrm{g}^{-1}\right.$ fresh weight) in the fifth fully developed leaf of pepper plants

\begin{tabular}{lllcccr}
\hline Treatments & Chl. $a$ & Chl. $b$ & Carotenoids & $\begin{array}{c}\text { Chl. } \\
a / b \text { ratio }\end{array}$ & $\begin{array}{c}\text { Chl. } \\
(a+b)\end{array}$ & Chl. $(a+b) /$ Car. ratio \\
\hline $1^{*}$ & $1.00 \mathrm{a}^{* *}$ & $0.44 \mathrm{a}$ & $0.42 \mathrm{a}$ & $2.27 \mathrm{a}$ & $1.44 \mathrm{a}$ & $3.42 \mathrm{a}$ \\
2 & $1.36 \mathrm{~b}$ & $0.63 \mathrm{~b}$ & $0.52 \mathrm{ab}$ & $2.16 \mathrm{~b}$ & $1.99 \mathrm{~b}$ & $3.83 \mathrm{a}$ \\
3 & $1.33 \mathrm{~b}$ & $0.75 \mathrm{c}$ & $0.62 \mathrm{~b}$ & $1.77 \mathrm{~d}$ & $2.08 \mathrm{c}$ & $3.35 \mathrm{a}$ \\
4 & $1.39 \mathrm{~b}$ & $0.69 \mathrm{bc}$ & $0.59 \mathrm{ab}$ & $2.01 \mathrm{c}$ & $2.08 \mathrm{c}$ & $3.53 \mathrm{a}$ \\
\hline
\end{tabular}

****Explanations: see Table 4 
Table 6. Leaf gas exchange in the fifth fully developed leaf of pepper plants

\begin{tabular}{|c|c|c|c|}
\hline Treatments & 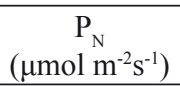 & 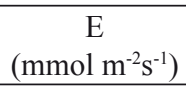 & 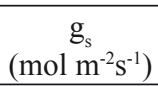 \\
\hline $1 *$ & $14.08 \mathrm{a}^{* *}$ & $1.19 \mathrm{a}$ & $0.05 \mathrm{a}$ \\
\hline 2 & $16.09 \mathrm{~b}$ & $1.51 \mathrm{ab}$ & $0.09 \mathrm{~b}$ \\
\hline 3 & $20.68 \mathrm{c}$ & $1.62 \mathrm{ab}$ & $0.07 \mathrm{~b}$ \\
\hline 4 & $19.17 \mathrm{c}$ & $2.23 \mathrm{~b}$ & $0.12 \mathrm{c}$ \\
\hline
\end{tabular}

PN - Net photosynthesis; E - Transpiration rate; $g_{s}$ - Stomatal conductance

*,**Explanations: see Table 4

Table 7. Pollen fertility (\%) in 'Buketen 50’ pepper plants after Lumbrical biofertilizer application

\begin{tabular}{|c|c|c|c|c|c|c|c|c|}
\hline Treatments & $\bar{x}$ & $\mathrm{VC}$ & \multicolumn{5}{|c|}{ (from - to; in days) } & $90-100$ \\
\hline $1^{*}$ & 68.5 & 14.9 & 8.8 & 11.3 & 10.0 & 22.5 & 24.9 & 22.5 \\
\hline 3 & 72.9 & 10.9 & 5.7 & 7.5 & 11.8 & 10.8 & 34.5 & 29.7 \\
\hline 4 & 65.5 & 22.8 & 7.2 & 8.3 & 10.9 & 14.9 & 29.9 & 28.8 \\
\hline
\end{tabular}

$\bar{x}$ - average rate; $\mathrm{VC}$ - variation coefficient (\%)

*Explanations: see Table 4

Table 8. Pepper yield (raw material for drying) and total pigment content (ASTA units) in red pepper fruits

\begin{tabular}{|c|c|c|c|c|c|}
\hline Treatments & Number of fruits per plant & $\begin{array}{l}\text { Fruit weight } \\
(\mathrm{g})\end{array}$ & $\begin{array}{l}\text { Pericarp thickness } \\
(\mathrm{mm})\end{array}$ & $\begin{array}{c}\text { Total yield } \\
\left(\mathrm{kg} \mathrm{ha}^{-1}\right)\end{array}$ & $\begin{array}{l}\text { ASTA } \\
\text { (units) }\end{array}$ \\
\hline $1 *$ & $9.9 \mathrm{a}^{* *}$ & $16.5 \mathrm{a}$ & $1.6 \mathrm{a}$ & $7559 \mathrm{a}$ & $193 \mathrm{a}$ \\
\hline 2 & $12.9 \mathrm{~b}$ & $17.0 \mathrm{~b}$ & $2.9 \mathrm{~b}$ & $8562 \mathrm{~b}$ & $197 b$ \\
\hline 3 & $14.8 \mathrm{c}$ & $18.2 \mathrm{c}$ & $3.2 \mathrm{c}$ & $9781 \mathrm{~d}$ & $242 \mathrm{~d}$ \\
\hline 4 & $12.4 \mathrm{~b}$ & $18.4 \mathrm{c}$ & $3.1 \mathrm{bc}$ & $9323 \mathrm{c}$ & $258 \mathrm{~d}$ \\
\hline
\end{tabular}

****Explanations: see Table 4

determined in the flowers of plants additionally treated in the vegetation period. The obtained results show that higher yield can be expected in the indicated variant, compared with the rest of the variants.

Table 8 shows that the yield of the plants treated with Lumbrical was higher than that of the control sample. A tendency for an increase in the average fruit mass and the pericarp thickness (the main material for preparation of grinded pepper) is observed. The increase in the yield under the influence of the biofertilizer was observed in other crops: aubergine and carrots (Tomar et al. 1998), as well as potatoes (Mrinal-Saikia et al. 1998). According to some authors (Arancon et al. 2004), a positive correlation between the yield and the content of mineral nitrogen in the biofertilizer or in the plant is missing. However, the increase in the yield may be explained by the increased population of useful soil microorganisms and the increased intensity of the processes in which they are involved, which in turn, preconditions better plant nutrition (Tringovska and Kanazirska 2003).

The pigment content is an important index determining the quality of the red pepper for grinding (Todorova et al. 1999). In the present study, the rates of the ASTA units were highest when a higher level of nutrition with Lumbrical was applied.

\section{CONCLUSIONS}

On the basis of the obtained results it was concluded that:

1. Nutrition with Lumbrical biofertilizer enhanced plant growth. The increased growth rate of the vegetative organs was accompanied by enhanced development of the generative ones.

2. The positive effect of the biofertilizer on the functional activity of the photosynthetic apparatus was expressed through an increased content of the photosynthetic pigments and improved leaf gas exchange parameters.

3. The highest rates of pollen fertility were determined in plants additionally treated with Lumbrical.

4. The yield was positively influenced by the biofertilizer Lumbrical. A clear tendency for increase in the average fruit mass and the pericarp thickness was observed. The pigment content was higher in the variants treated with biofertilizer. 


\section{ACKNOWLEDGEMENTS}

We would like to express our gratitude to Mrs. G. Pevicharova from The Maritsa Vegetable Crops Research Institute for helping in the determination of pigment content in red pepper fruits.

\section{REFERENCES}

Aliyu L., Kuchinda N., 2002. Analysis of the chemical composition of some organic manures and their effect on the yield and composition of pepper. Crop Res. (Hisar) 23(2): 362-368.

Arancon N., Edwards C., Atiyeh R., Metzger J., 2004. Effects of vermicomposts produced from food waste on the growth and yields of greenhouse peppers. Bioresource Technol. 93(2): 139-144.

Atiyeh R., Arancon N., Edwards A., Metzeger J., 2000. Influence of earthworm-produced pig manure on the growth and yield of greenhouse tomatoes. Bioresource Technol. 75(3): 175-180.

BARAKrT M., Gabr S., 1998. Effect of different biofertilizer types and nitrogen fertilizer levels on tomato plants. Alexandria J. Agricult. Res. 43(1): 149-160.

Clive A., Arancon E., Arancon N., 2006. Mechanisms by which earthworms interact with plant pathogens, plant parasitic nematodes and invertebrate pest arthropods. The $8^{\text {th }}$ Intl. Symp. on Earthworm Ecol., Krakow, Poland, 04-09 September: 237.

Gutierrez-Miceli F., Santiago-Borraz J., Montes Molina J., Nafate C., Abdu-Archila M., Oliva Llaven M., RinconRosales R., Dendooven L., 2007. Vermicompost as a soil supplement to improve growth, yield and fruit quality of tomato (Lycopersicum esculentum). Bioresource Technol. 98(15): 2781-2786.

Hashemimajd K., Kalbasi M., Colchin A., Shariatmadari H., 2004. Comparison of vermicompost and composts as potting media for growth of tomatoes. J. Plant Nutr. 27(6): 1107-1124.

Heeb A., Lundegårdh B., Ericsson T., Savage G., 2005. Effects of nitrate-, ammonium-, and organic-nitrogenbased fertilizers on growth and yield of tomatoes. J. Plant Nutr. Soil Sci. 168(1): 123-129.

Karbauskiene E., 2000. The influence of organic fertilizers on microorganisms in tomato rhizosphere. Hort. Veg. Grow. 19(1): 122-133.

KoleshKo O., 1981. Ecology of microorganisms in the soil. Minsk: 172.

Kostadinova P., Lecheva I., Bencheva N., Angelova R., Popov V., 2003. Agroecology and management of agroecosystems. Publish SciSet-Eco, Sofia.

Lichtenthaler H., Wellburn A., 1983. Determination of total carotenoids and chlorophyll $\mathrm{a}$ and $\mathrm{b}$ of leaf extracts in different solvents. Biochem. Soc. Trans. 603: 591-592.

Makulec G., 2002. The role of Lumbricus rubellus Hoffm. In determining biotic and abiotic properties of peat soils. Polish J. Ecol. 50(3): 301-339.
MANUELYAN H., 1979. Use of ethyl alcohol for the determination of pigment substance concentration in red pepper. Hort. Viticul. Sci. 1: 91-96.

Mrinal-Saikia D., Raykhowa J., Saikia M., 1998. Effect of planting density and vermicompost on yield of potato rised from seedling tubers. J. Indian Potato Assn. 25(3-4): 141-142.

Singh R. Sharma R., Kumar S., Gupta R., Patil R., 2008. Vermicompost substitution influences growth, physiological disorders, fruit yield and quality of strawberry (Fragaria $\times$ ananassa Duch.). Bioresource Technol. 99(17): 8507-8511.

Stephen F., Nybe E., 2003. Organic manures and biofertilizers on nutrient availability and yield in black pepper. J. Trop. Agr. 41(1-2): 52-55.

Todorova V., Pevicharova G., Todorov Y., 1999. Total pigment content in red pepper cultivars for grinding. Capsicum and Eggplant Newsletter 18: 25-27.

Tomar V., Bhatnagar R., Palta R., 1998. Effect of vermicompost on production of brinjal and carrot. Bhartiya Krishi Anusandhan Petrika 13(3-4): 153-156.

Tomov T., Rachovski G., Kostadinova S., Manolov I., 1999. Guide to Agrochemistry. Acad. Publ. Higher Inst. Agr., Plovdiv.

Tringovska I., KanAZIRSKA V., 2003. Use of biohumus in greenhouse vegetable production, $\mathrm{IV}^{\text {th }}$ Scientific and Practical Conf. "Ecological problems of agriculture" Agroeco XLVIII, Plovdiv, Bulgaria, 19 May: 317-322.

TringovskA I., 2004. Influence of bacterial fertilizers on biological manifestations of tomatoes. $\mathrm{V}^{\text {th }}$ National Scientific and Technical Conf. "Ecology and health", Plovdiv, Bulgaria, 20 May: 233-238.

\section{WPEYW NAWOŻENIA ORGANICZNEGO NA WZROST I WYDAJNOŚĆ PAPRYKI (CAPSICUM ANNUM L.)}

Streszczenie: Celem doświadczenia było zbadanie wpływu nawożenia nawozem organicznym Lumbrical na wzrost i plon oraz niektóre parametry fizjologiczne papryki ('Buketen 50'). Badania przeprowadzono na polu doświadczalnym Centrum Agroekologicznego przy Uniwersytecie Rolniczym w Płowdiw (Bułgaria), posiadającym certifikat gospodarstwa ekologicznego. Nawóz Lumbrical jest produkowany przy wykorzystaniu dżdżownicy kalifornijskiej (Lumbricus rubellus). Bezpośrednio przed sadzeniem roślin zastosowano dwa poziomy nawożenia nawozem Lumbrical, tj. 50 i $100 \mathrm{ml}$ na roślinę. 30 dni po sadzeniu roślin część $\mathrm{z}$ nich dodatkowo zasilono roztworem Lumbricalu (200 $\mathrm{ml}$ na roślinę). W okresie wegetacji zbadano wybrane wskaźniki charakteryzujące wzrost roślin. Określono zawartość pigmentów i wymianę gazową liści oraz płodność pyłku. W wysuszonych owocach ustalono zawartość barwników.

Received May 25, 2009; accepted April 15, 2010 